\title{
Pensononowoor
}

2017, vol. 78, 51-62

http://dx.doi.org/10.12657/denbio.078.006

\author{
Girmantè Jurkšienè, Dalia Janušauskaitè, Kęstutis Armolaitis, \\ Virgilijus Baliuckas
}

\section{Leaf litterfall decomposition of pedunculate (Quercus robur L.) and sessile (Q. petraea [Matt.] Liebl.) oaks and their hybrids and its impact on soil microbiota}

Received: 18 August 2016; Accepted: 31 March 2017

\begin{abstract}
Trakas Forest is the only natural habitat of sessile oak in Lithuania. Sessile oak stand here is growing about $60-70 \mathrm{~km}$ from the nearest natural sessile oak stands in Poland. The purpose of this study was to determine whether autumn leaf litterfall of pedunculate and sessile oaks and their hybrids have different biochemical composition and decomposition rate and, consequently, different impacts on microbial condition of rhizosphere. For this purpose in autumn leaf litterfall C, N, P, K, Ca, Mg, lignin, ash, fat, crude fibre and water-soluble carbohydrates contents and stocks, lignin/N, lignin/P, C/N, C/P, N/P ratios, the decomposition rate and $\mathrm{CO}_{2}$ emissions were determined. In rhizosphere of studied oak species $\mathrm{N}$, $\mathrm{C}$ concentration, $\mathrm{pHH}_{2} \mathrm{O}, \mathrm{C} / \mathrm{N}$ ratio, and dehydrogenase, urease, phosphatase, bacteria and micromycetes amount were estimated as well. The litterfall of pedunculate oak was distinguished by a higher content of lignin, higher lignin/ $\mathrm{N}$ ratio, lower decay rate and lower carbon release, which determines decreased activity of micromycetes in the rhizosphere. Metabolic activity of microorganisms differed insignificantly among tree species rhizospheres. However, the potential for the use of carbon compound substrates and biodiversity index have a tendency to be higher in the soil under sessile oak. Lower decomposition rate of leaf litterfall and organic compounds in the rhizosphere under pedunculate oak allowed to suppose that the conditions for natural regeneration were more suitable in stands where sessile and hybrid oaks dominate.
\end{abstract}

Keywords: biochemical properties, enzymatic activity, metabolic activity, microorganisms, microbial communities.

Addresses: G. Jurkšienė, K. Armolaitis, V. Baliuckas, Institute of Forestry, Lithuanian Research Centre for Agriculture and Forestry, Liepų str. 1 Girionys, LT-53101 Kaunas distr., Lithuania,

e-mail: Girmante.Jurksiene@mi.lt

D. Janušauskaitė, Institute of Agriculture, Lithuanian Research Centre for Agriculture and Forestry, Akademija, LT-58344 Kèdainiai distr., Lithuania

K. Armolaitis, Faculty of Natural Science, Vytautas Magnus University, Vileikos 8, LT-44404 Kaunas, Lithuania

V. Baliuckas, Institute of Forest Biology and Silviculture, Aleksandras Stulginskis University, Studentų str. 11, LT-53361 Akademija, Kaunas distr., Lithuania 


\section{Introduction}

Sessile oak (Quercus petraea [Matt.] Liebl.) in Trakas Forest in the south-western part of Lithuania was discovered in a 70 ha area by S. Tuminauskas in 1954 (Tuminauskas, 1957). In Trakas Forest, sessile oak grows at the eastern edge of the distribution area. This stand is growing about $60-70 \mathrm{~km}$ from the nearest natural sessile oak stands in Poland (Navasaitis et al., 2003). Pedunculate oak (Q. robur L.) comprised up to $44 \%$, sessile oak $18 \%$, and trees possessing features of hybrids $38 \%$ of the total number of oaks in Trakas Forest (Baliuckas, 2000). Oak undergrowth consists of only $5 \%$ sessile oak, $20 \%$ hybrids and the remaining $75 \%$ pedunculate oak $\mathrm{OJ}-$ rkšienè et al., 2012). A fairly high degree of hybridization (15-55\%) was determined by Carlisle and Brown (1965), Wigston (1975) and Kissling (1980a; 1980b; 1983) in Switzerland, Rushton (1978; 1979; 1983), Minihan and Rushton (1984) in the United Kingdom and Jensen et al. (2009) in Denmark. However, lower rates of hybridization were obtained in similar studies made in Central Europe (Aas, 1993; Steinhoff, 1998; Streiff et al., 1999).

Tree foliar litterfall is very important for the initial biological cycle process in forest stands (Kaiser et al., 2011; Strickland et al., 2013). On decomposition of forest floor the nutrients, mainly organic carbon and nitrogen, return to the soil's available nutrient pool, where they are reused by plants (Osman, 2013). Therefore, it is known that the chemical composition of mineral topsoil can be tightly related to the chemical composition of the forest floor by the nutrient resorption during senescence (Hobbie et al., 2006).

Leaf litter of different oak species is highly lignified (Sinsabaugh et al., 2002) and decomposes slowly, resulting in slower nutrient release (Hobbie et al., 2006). Therefore, a high oak quantity in forests may increase carbon storage in the forest floor through lower rates of litter decomposition and potential nutrient availability from delayed litter mineralization (Piatek et al., 2009). Chávez-Vergara et al. (2016) propose that Quercus species influence the organic nutrient mineralization by determining the composition and activity of the forest floor microbial communities.

Soil enzymatic activities are important for the biological decomposition cycle process and were suggested as potential indicators of soil quality, especially for changes of forest floor properties (Bolton et al., 1985; Kandeler et al., 1996; Yang et al., 2006; Hussain et al., 2009; Das \& Varma, 2011; Utobo \& Tewari, 2015). Numerous studies confirmed that dehydrogenase is involved in the initial oxidation of soil organic matter and phosphatase predicts organic phosphorus mineralization, while urease is involved in nitrogen cycling (Tabatabai \& Bremner, 1972; Amador et al., 1997; Krämer \& Green, 2000; Quilchano
\& Maranon, 2002). Consequently, the dehydrogenase activities in soil are biological indicators of overall microbial respiratory activity of soils and are used by microorganisms in the soil to break down organic matter (Bolton et al., 1985; Utobo \& Tewari, 2015). Other soil enzymes urease and phosphatase have a crucial role in $\mathrm{N}$ and $\mathrm{P}$ cycle respectively (Karaca et al., 2011). In addition, the activity of phosphatases was found to correlate with organic matter in various studies (Guan, 1989; Jordan \& Kremer, 1994; Aon et al., 2001) according to Das and Varma (2011), it is crucial for predicting their interactions as their activities may, in turn, regulate nutrient uptake and plant growth.

This work could be distinguished from similar studies, as the research object includes sessile oak habitat at the edge of species natural distribution. We hypothesized that the higher species decomposition rate of litterfall under different oak species, the less lignin concentration and lignin/ $\mathrm{N}$ ratio as well create better conditions to natural regeneration of undergrowth (could influence natural regeneration and expansion of sessile and hybrid oak). The purpose of this study was to determine whether autumn leaf litterfall of pedunculate and sessile oaks and their hybrids have different biochemical composition and decomposition rate and, consequently, different impacts on microbial condition of rhizosphere.

\section{Materials and methods}

\section{Study site and sampling}

Autumn leaf litterfall (hereafter - leaf litter) and soil samples were collected in Trakas Forest (54¹4'11"N, 2345'30”E, $190 \mathrm{~m}$ a.s.1.), $2 \mathrm{~km}$ west from Seirijai in Alytus district, south-west Lithuania (Fig. 1). This forest has had the status of a strict nature botanical-zoological reserve in Meteliai Regional Park since 1960. Pure pedunculate and sessile oak stands occupy only $9 \%$ of the total Trakas Forest area and in $49 \%$ of the forest area they are an admixture mainly with Scots pine (Pinus sylvestris L.), Norway spruce (Picea abies (L.) H. Karst.), silver birch (Betula pendula Roth.), etc. (Tuminauskas, 1957; Patalauskaite, 2008). The main forest site type according to Lithuanian classification is mesoeutrophic mineral soils of normal moisture (Nc), while the soil according to World Reference Base for Soil Resources was classified as Luvisols (sandy loam over sandy clay loam) (LR AM/LMI/MVT, 2006; WRB, 2014). The forest belongs to the Querco-Fagetea class, Fagetalia sylvaticae Pawłowski 1928 order, Carpinion betuli alliance, Tilio-Carpinetum betuli Traczyk 1962 association and the calamagrostetosum subassociation (Patalauskaitè, 2007). 


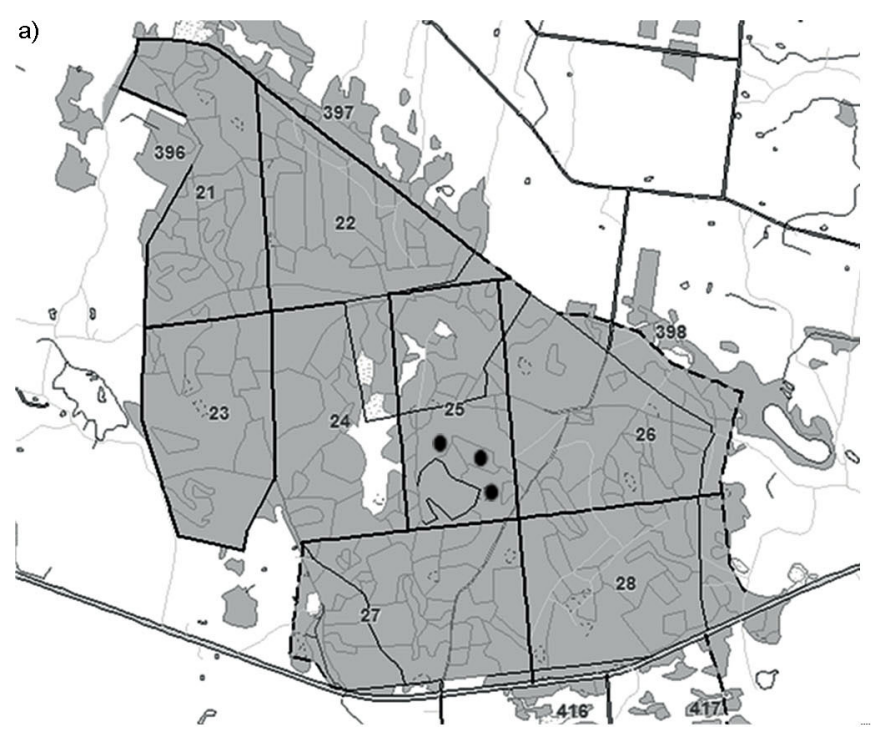

b)

Fig. 1. Trakas Forest in Alytus district, Veisiejai Forest Enterprise, Seirijai Forest District in Lithuania (54 $14^{\prime} 11^{\prime \prime N}$, 234'30”,E, $190 \mathrm{~m}$ a.s.l.): a) Trakas Forest; numbers and lines indicate forest blocks, larger black circles - the three sampling sites; b) rectangular shows the location of Trakas Forest in Lithuania and smaller black circles - the nearest natural sessile oak stands in Poland

From the data of the Lazdijai hydro-meteorological station which is located at a distance of $16 \mathrm{~km}$ from Trakas Forest, the mean annual temperature in this region was $6.5-7{ }^{\circ} \mathrm{C}$ and annual precipitation 650-700 mm (Galvonaitè et al., 2013). During soil and leaf litter summer sampling in June 2011, the mean temperature was $17.8^{\circ} \mathrm{C}\left(\min -5^{\circ} \mathrm{C}\right.$, max $30^{\circ} \mathrm{C}$ ) and precipitation was $70 \mathrm{~mm}$ (LHMT/AM, 2011a). During autumn sampling in November 2011 and 2012 , mean monthly temperature was $3.0-4.6^{\circ} \mathrm{C}$ (min --6 and $-1^{\circ} \mathrm{C}$, max -10 and $11^{\circ} \mathrm{C}$ respectively), while the amount of precipitation in 2011 was 34 $\mathrm{mm}$ or two times lower than in 2012 (LHMT/AM, 2011b; LHMT/AM, 2012).

The area of investigated oak stand was about 20 ha. Oak species are mixed in different proportions in this stand, so three sites were selected where both oak species and their hybrids were present. The samples of leaf litter (soil organic OL horizon) and mineral soil (at $0-15 \mathrm{~cm}$ in depth) were collected at three sites in Trakas Forest where pedunculate and sessile oaks and their hybrids were presented together (Fig. 1): first site $-54^{\circ} 14^{\prime} 13^{\prime \prime} \mathrm{N}, 23^{\circ} 45^{\prime} 20^{\prime \prime} \mathrm{E}, 172 \mathrm{~m}$ a.s.l.; second site $-54^{\circ} 14^{\prime} 12^{\prime \prime} \mathrm{N}, 23^{\circ} 45^{\prime} 38^{\prime \prime}$ E, $184 \mathrm{~m}$ a.s.l.; third site $-54^{\circ} 14^{\prime} 07^{\prime \prime} \mathrm{N}, 23^{\circ} 45^{\prime} 38^{\prime \prime} \mathrm{E}, 176 \mathrm{~m}$ a.s.l. The average distance between all three studied sites was around $200 \mathrm{~m}$, while in each site of each oak sampling area was about $20 \times 20 \mathrm{~m}^{2}$. The composite samples of leaf litter were collected in November 2011 and 2012. Mineral soil samples at $0-15 \mathrm{~cm}$ in depth at each site were collected in June 2011. November 2011 and 2012 composite samples in each of three sites were taken so as to form a triangle around the tree stem (the distance between points is more than $5 \mathrm{~m}$ ) under pedunculate oak, sessile oak and their hybrids.
For leaf litter sampling hybrids of pedunculate and sessile oaks were identified by their morphological leaf characteristics (Jurkšienè et al., 2014). With the same sampling design for the calculation of leaf litter mass, the samples were collected with a $0.1 \mathrm{~m}^{2}$ metallic circular frame in November 2013. In both cases, nine composite samples (from three repeats at each point) were collected in total. In order to determine the dry mass, the samples of leaf litter were oven-dried at $105 \pm 5{ }^{\circ} \mathrm{C}$ and weighed (ISO 11465:1993).

Composite mineral soil samples with a minimum of $1 \mathrm{~kg}$ of soil were mixed thoroughly and placed in tightly sealed plastic bags and kept at $4{ }^{\circ} \mathrm{C}$ to retain field moisture for microbial analyses. All microbial determination was performed within one week of sampling (Öhlinger, 1996). Soil moisture content was determined gravimetrically after drying soil samples at $105^{\circ} \mathrm{C}$.

\section{Leaf litter and soil biochemical analysis}

Leaf litter and soil biochemical analyses were performed in the Chemical Research Laboratory of the Institute of Agriculture, Lithuanian Research Centre for Agriculture and Forestry (Akademija, Lithuania) as described previously (Janušauskaitè et al., 2013). The concentration of total organic carbon (C) and total phosphorus $(\mathrm{P})$ in leaf litter was determined using an automatic UV/VIS Carry 50 spectrophotometer (Varian, Germany). Total nitrogen (N) concentration in leaf litter was determined by the Dumas method. Other major elements such as potassium $(\mathrm{K})$, calcium $(\mathrm{Ca})$ and magnesium $(\mathrm{Mg})$ were measured using a Perkin Elmer Instrument Analyst 200 flame atomic absorption spectrometer. Lignin (acid detergent lignin) was 
estimated using the cell wall detergent fractionation method according to the Van Soest methodology of fibre fractionation (Van Soest et al., 1991). Ash was determined by combustion and digestibility of the dry matter in vitro using the pepsin-cellulase method. Fat was determined by Soxhlet apparatus using the gravimetric method. Crude fibre (CF) was defined using an NIRS-6500 near infrared spectrometer (Perstorp Analytical, Silver Spring, Maryland, USA). Concentrations of water-soluble carbohydrates (WSC) were evaluated using the Anthrone method, while $\mathrm{pH}_{\mathrm{H} 2 \mathrm{O}}$ in soil and leaves was measured using a WTW Inolab $\mathrm{pH}$ meter. The total soil $\mathrm{N}$ and $\mathrm{C}$ were determined using the dry combustion method (DIN/ISO 13878 1998). In addition, the ratios of concentration Lignin/ $\mathrm{N}$, Lignin/ $\mathrm{P}$, $\mathrm{C} / \mathrm{N}, \mathrm{C} / \mathrm{P}, \mathrm{N} / \mathrm{P}$ were calculated.

Biochemical characteristics of stocks $\left(\mathrm{g} \mathrm{m}^{-2}\right)$ in leaf litter of the studied oaks were calculated by multiplying the dry mass of leaf litter $\left(\mathrm{kg} \mathrm{m}^{-2}\right)$ by the concentration $\left(\mathrm{g} \mathrm{kg}^{-1}\right)$ of the biochemical parameters.

\section{Leaf litter decomposition study}

Leaf litter decomposition studies and soil enzymatic, biological and metabolic activities were performed in the Department of Plant Pathology and Protection of the Institute of Agriculture, Lithuanian Research Centre for Agriculture and Forestry (Akademija, Lithuania) as described previously (Janušauskaitė et al., 2013). For respiration measurements of $\mathrm{CO}_{2}$ emission, beakers $(\mathrm{n}=3)$ with $1 \mathrm{~g}$ leaf litter samples were placed in a $1 \mathrm{l}$ air-tight jar with $10 \mathrm{ml} \mathrm{H}_{2} \mathrm{O}$ at the bottom and with $\mathrm{aCO}_{2}$ trap $(10 \mathrm{ml}$ of $0.5 \mathrm{M} \mathrm{NaOH})$ and incubated in total darkness at $17^{\circ} \mathrm{C}$. The samples were moistened with mineral soil suspension. Soil suspensions were prepared by shaking $10 \mathrm{~g}$ of soil with $100 \mathrm{ml}$ of distilled water for $15 \mathrm{~min}$. Portions (3 $\mathrm{ml}$ ) were extracted from the suspensions and applied to each beaker in order to inoculate litter samples with microorganisms. The traps were replaced at 21 day intervals. The $\mathrm{CO}_{2}$ released was determined by titration with $\mathrm{HCl}(0.25 \mathrm{M})$, combined with $1 \mathrm{ml}$ of $\mathrm{BaCl}_{2}(1.0 \mathrm{M})$ and five drops of phenolphthalein solution $(0.1 \%$ in $60 \%$ ethanol), until the solution had changed from pink to cloudy white. The measurement was performed in triplicate for each litter sample. Respiration was expressed as $\mu \mathrm{g} \mathrm{CO}_{2}-\mathrm{C} \mathrm{g}^{-1}$ leaf litter and measured in a closed environment after each 21 days. The incubation lasted for 105 days in 2011 and 125 days in 2012 (Ayres et al., 2006).

In addition, the mean decomposition constant $\left(k_{w}\right)$ of leaf litter for the mentioned incubation periods was calculated using the negative exponential decay model (Olson, 1963):

$$
W_{t}=W_{0} \mathrm{e}^{-k t}
$$

where $W_{0}$ is initial weight ( $1 \mathrm{~g}$ of dry litter) and $W_{t}$ is the weight remaining after time period $t$ (the end of the experiment, 105 or 125 days).

\section{Soil enzymatic activity}

Fresh mineral soil samples were used for all enzyme analyses. Dehydrogenase (EC 1.1) was determined using the reduction of 2,3,5-triphenyltetrazolium chloride (TTC) to triphenyl formazan (TPF) method and results were expressed as $\mu \mathrm{g}$ TPF $\mathrm{g}^{-1}$ soil dry weight (DW) $24 \mathrm{~h}^{-1}$ (Öhlinger, 1996). Urease (EC 3.5.1.5) estimation was based on the colorimetric determination of ammonium formation after enzymatic urea hydrolysis by the buffered method (Kandeler, 1996). The released ammonium was determined spectrophotometrically at $630 \mathrm{~nm}$. The results were expressed in $\mu \mathrm{g} \mathrm{NH}_{4} \mathrm{~g}^{-1} \mathrm{DW}$ soil. For alkaline phosphatase (EC 3.1.3.1), soil samples (1.0 g) were reacted with substrate $(50 \mathrm{mM}$ sodium p-nitrophenyl phosphate) (Margesin, 1996). The yellow colour intensity of the released p-nitrophenol was measured at $400 \mathrm{~nm}$ using a spectrophotometer after incubation at $37^{\circ} \mathrm{C}$ for $1 \mathrm{~h}$. All analyses were carried out in triplicate and expressed per $\mathrm{g}$ of dry mass of soil.

\section{Soil biological activity}

Composite soil samples were passed through a 2 $\mathrm{mm}$ sieve before the analyses. Conventional dilution spread-plating was performed in order to assess the cultural fungal and bacterial colony forming units (CFU) (Trolldenier, 1996). Total abundance of fungi was enumerated by plating the dilution series onto malt extract agar and heterotrophic bacteria on soy agar medium. All inoculated media was incubated at room temperature $\left(22 \pm 3^{\circ} \mathrm{C}\right)$ for ca. $3,5,10$ and 40 days. All microbial enumerations were carried out in triplicate. Data is reported in $10^{4} \mathrm{CFU} \mathrm{g}{ }^{-1} \mathrm{DW}$ soil.

\section{Determination of microbial communities using Biolog EcoPlates}

Biolog EcoPlates (Biolog Inc., Hayward CA., USA) ( $n=3$ under each studied oak) were used to determine soil microbial functional diversity based on the utilization of 31 carbon substrates. Analysis was carried out as described by Insam \& Goberna (2008) according to protocol 1 .

AWCD (average well colour development) was calculated from each plate at each reading time (24 hours, 48 hours, 72 hours) with a microplate reader, using Biolog MicroLog ${ }^{\mathrm{TM}}$ 3E. Diversity parameters were calculated using the following two equations (Insam \& Goberna, 2008): 


$$
S h=-\sum p_{i}\left(\ln p_{i}\right)
$$

where $S h$ is Shannon's diversity index and $p_{i}$ is the ratio of the corrected absorbance value of each well to the sum of the absorbance value of all wells;

$$
E=S h / \log R^{\prime}(3)
$$

where $E$ is substrate evenness, $S h$ is Shannon's diversity index and $R$ (substrate richness) is the number of different substrates used by the community (counting all positive optical density readings).

\section{Statistical analysis}

Data are reported as means with the standard error and were examined using analysis of variance (one-way ANOVA) procedures with the STATISTICA 8.0 program. The purpose of ANOVA was to test the significant differences of obtained data for pedunculate oak $(\mathrm{P})$, sessile oak $(\mathrm{S})$ and their hybrids $(\mathrm{H})$. In cases when data did not hold the requirement for normal distribution, Mann-Whitney test was applied.

\section{Results and discussion}

\section{Biochemical properties of leaf litter an soil}

First of all, it is purposive to show how the biochemical composition of the leaf litter of the studied oak species and their hybrids differed. As can be seen in Table 1, the mean $\mathrm{pH}_{\mathrm{H} 2 \mathrm{O}}$ parameter and mean concentrations of $\mathrm{C}, \mathrm{P}, \mathrm{K}, \mathrm{Ca}, \mathrm{Mg}$, ash, fat, $\mathrm{CF}$ and WSC did not significantly differ $(p>0.05)$ in the leaf litter of the studied oak species and their hybrids. Only mean concentrations of total $\mathrm{N}$ were significantly $(12-13 \%)$ higher $(p<0.05)$ in the leaf litter of hybrid oak than in pedunculate oak. Also, mean lignin concentration was $11 \%$ higher in the leaf litter of pedunculate oak compared with sessile oak. Mean lignin concentrations in the leaf litter of hybrids were intermediate, with no significant differences from the leaf litter of other oaks.

Only the mean concentrations of lignin/ $\mathrm{N}$ and $\mathrm{N} / \mathrm{P}$ ratios differed significantly $(\mathrm{p}<0.05)$. As can be seen in Table 1, mean lignin/ $\mathrm{N}$ ratio was the highest by $15-18 \%$ in pedunculate oak leaf litter, which contained the lowest concentration of N. Mean N/P ratios were the highest, about $42-47 \%$, in sessile oak leaf litter compared to pedunculate and hybrid oaks.

Lignin/ $\mathrm{N}$, lignin/P, $\mathrm{C} / \mathrm{N}, \mathrm{C} / \mathrm{P}$ and $\mathrm{N} / \mathrm{P}$ ratios reflect immobilization of $\mathrm{C}, \mathrm{N}$ and $\mathrm{P}$ organic compounds, or the opposite intensity of mineralization of organic matter (Gosz et al., 1973; Edmonds et al., 1980; Koerselman \& Meuleman, 1996; Moore et al.,
Table 1. Mean $\mathrm{pH}$ and mean concentrations of biochemical parameters (expressed on a DW basis, $\mathrm{g} \mathrm{kg}^{-1}$ ) and some of their ratios in autumn leaf litterfall of pedunculate (P) and sessile (S) oak and their hybrids $(\mathrm{H})$ in Trakas Forest, Lithuania

\begin{tabular}{lccc}
\hline \multicolumn{1}{c}{ Parameter } & $\mathrm{P}$ & $\mathrm{S}$ & $\mathrm{H}$ \\
\hline $\mathrm{C}$ & $622.2 \pm 15.7 \mathrm{a}$ & $611.0 \pm 14.6 \mathrm{a}$ & $613.7 \pm 15.4 \mathrm{a}$ \\
$\mathrm{N}$ & $11.2 \pm 0.3 \mathrm{a}$ & $11.8 \pm 0.6 \mathrm{ab}$ & $12.6 \pm 0.4 \mathrm{~b}$ \\
$\mathrm{P}$ & $1.51 \pm 0.20 \mathrm{a}$ & $1.10 \pm 0.06 \mathrm{a}$ & $1.71 \pm 0.32 \mathrm{a}$ \\
$\mathrm{K}$ & $6.42 \pm 0.97 \mathrm{a}$ & $5.75 \pm 1.18 \mathrm{a}$ & $6.84 \pm 2.25 \mathrm{a}$ \\
$\mathrm{Ca}$ & $14.71 \pm 8.19 \mathrm{a}$ & $15.51 \pm 6.33 \mathrm{a}$ & $14.17 \pm 7.29 \mathrm{a}$ \\
$\mathrm{Mg}$ & $3.39 \pm 1.20 \mathrm{a}$ & $3.11 \pm 0.91 \mathrm{a}$ & $3.35 \pm 1.11 \mathrm{a}$ \\
$\mathrm{pH}_{\mathrm{H}_{2} \mathrm{O}}$ & $4.56 \pm 0.30 \mathrm{a}$ & $4.58 \pm 0.37 \mathrm{a}$ & $4.66 \pm 0.30 \mathrm{a}$ \\
Lignin $_{\text {Ash }}$ & $435.9 \pm 8.8 \mathrm{~b}$ & $391.5 \pm 12 . \mathrm{a}$ & $411.6 \pm 8.8 \mathrm{ab}$ \\
Fat & $55.2 \pm 5.9 \mathrm{a}$ & $52.9 \pm 3.2 \mathrm{a}$ & $53.6 \pm 3.3 \mathrm{a}$ \\
Crude fibre & $28.0 \pm 2.2 \mathrm{a}$ & $33.2 \pm 2.4 \mathrm{a}$ & $25.6 \pm 3.4 \mathrm{a}$ \\
Water-soluble & $21.3 \pm 1.5 \mathrm{a}$ & $17.4 \pm 4.1 \mathrm{a}$ & $15.0 \pm 1.4 \mathrm{a}$ \\
carbohydrates & $39.5 \pm 1.8 \mathrm{~b}$ & $34.5 \pm 2.1 \mathrm{ab}$ & $33.3 \pm 1.3 \mathrm{a}$ \\
Lignin/N & $310.0 \pm 16.0 \mathrm{a}$ & $413.0 \pm 17.0 \mathrm{a}$ \\
Lignin/P & $303.5 \pm 72.7 \mathrm{a}$ & $368.6 \pm 79.4 \mathrm{a}$ & $239.7 \pm 20.3 \mathrm{a}$ \\
$\mathrm{C} / \mathrm{N}$ & $55.8 \pm 2.5 \mathrm{a}$ & $52.9 \pm 3.5 \mathrm{a}$ & $48.9 \pm 2.3 \mathrm{a}$ \\
$\mathrm{C} / \mathrm{P}$ & $436.3 \pm 108.9 \mathrm{a}$ & $578.5 \pm 126.5 \mathrm{a}$ & $359.9 \pm 26.8 \mathrm{a}$ \\
$\mathrm{N} / \mathrm{P}$ & $7.7 \pm 1.4 \mathrm{ab}$ & $10.9 \pm 0.7 \mathrm{~b}$ & $7.4 \pm 0.1 \mathrm{a}$ \\
\hline
\end{tabular}

Notes: Results are expressed as the mean \pm SE $(n=9)$. Different letters in the same row indicate significant differences at $\mathrm{p}<$ 0.05 .

2006; Piatek et al., 2009). According to Hobbie et al. (2006), the decomposition of leaf litter of different tree species depends not only on lignin content, but also the lignin/ $\mathrm{N}$ ratio. A critical maximal value of the lignin/ $\mathrm{N}$ ratio in the range 23-25 indicates the beginning of recalcitrant lignin decomposition (Osono \& Takeda, 2004). However, as can be seen in Table 1, mean lignin/ $\mathrm{N}$ ratios (33-40) in the leaf litter of all studied oak species reflected the slow decomposition intensity of lignin in autumn. We did not find any published data on estimation of lignin/P ratios in leaf litter. The $\mathrm{C} / \mathrm{N}$ ratio for forest foliar litterfall can range from about 23-35 (Edmonds, 1979; 1980) to about 80 (Hart et al., 1992). According to our studies, mean $\mathrm{C} / \mathrm{N}$ ratios in the studied oak leaf litter varied from 49 to 56 . According to the studies of Rustad \& Cronan (1988) and Gosz et al. (1973), critical maximal $\mathrm{C} / \mathrm{P}$ ratio for $\mathrm{P}$ immobilization ranged from 350 to 480 . In our study, only the $\mathrm{C} / \mathrm{P}$ ratio in sessile oak leaf litter was in general higher (452-705) than the mentioned critical ratio. The above-mentioned data on $\mathrm{C} / \mathrm{N}$ and $\mathrm{C} / \mathrm{P}$ ratios also reflect the slow decomposition rate of organic compounds in leaf litter. A litter N/P concentration ratio $<16$ indicates mineralization of organic $\mathrm{P}$ and a ratio $<14$ indicates $\mathrm{N}$ limitation for the plants, while an N/P ratio $>16$ shows mineral P limitation for plants (Koerselman \& Meuleman, 1996; Moore et al., 2006) According to our research results (N/P varied from 7.4 to 10.9), leaf litter characterized from the studied oaks reflects $\mathrm{N}$ immobilization and mineralization of P. Limitation of $\mathrm{N}$ was the largest in hybrid oak leaf 
Table 2. Mean stocks of biochemical parameters (expressed on a DW basis, $\mathrm{g} \mathrm{m}^{-2}$ ) and some of their ratios in autumn leaf litterfall of pedunculate $(\mathrm{P})$ and sessile (S) oak and their hybrids $(\mathrm{H})$ in Trakas Forest, Lithuania

\begin{tabular}{lccc}
\hline \multicolumn{1}{c}{ Parameter } & $\mathrm{P}$ & $\mathrm{S}$ & $\mathrm{H}$ \\
\hline $\mathrm{C}$ & $237.2 \pm 5.9 \mathrm{a}$ & $241.6 \pm 5.8 \mathrm{a}$ & $311.7 \pm 7.8 \mathrm{~b}$ \\
$\mathrm{~N}$ & $4.3 \pm 0.1 \mathrm{a}$ & $4.6 \pm 0.2 \mathrm{a}$ & $6.4 \pm 0.2 \mathrm{~b}$ \\
$\mathrm{P}$ & $0.57 \pm 0.08 \mathrm{a}$ & $0.43 \pm 0.03 \mathrm{a}$ & $0.87 \pm 0.12 \mathrm{a}$ \\
$\mathrm{K}$ & $2.45 \pm 0.38 \mathrm{a}$ & $2.27 \pm 0.60 \mathrm{a}$ & $3.47 \pm 0.86 \mathrm{a}$ \\
$\mathrm{Ca}$ & $5.61 \pm 3.24 \mathrm{a}$ & $6.13 \pm 3.21 \mathrm{a}$ & $7.20 \pm 2.78 \mathrm{a}$ \\
$\mathrm{Mg}$ & $1.29 \pm 0.47 \mathrm{a}$ & $1.23 \pm 0.46 \mathrm{a}$ & $1.70 \pm 0.42 \mathrm{a}$ \\
Lignin & $166.2 \pm 3.4 \mathrm{a}$ & $154.8 \pm 4.9 \mathrm{a}$ & $209.0 \pm 4.5 \mathrm{~b}$ \\
Ash & $21.0 \pm 2.3 \mathrm{a}$ & $20.9 \pm 1.3 \mathrm{a}$ & $27.2 \pm 1.7 \mathrm{a}$ \\
Fat & $10.7 \pm 0.8 \mathrm{a}$ & $13.1 \pm 0.9 \mathrm{a}$ & $13.0 \pm 1.7 \mathrm{a}$ \\
Crude fibre & $142.2 \pm 0.8 \mathrm{a}$ & $162.1 \pm 6.3 \mathrm{a}$ & $209.7 \pm 8.6 \mathrm{~b}$ \\
Water-soluble & $8.1 \pm 0.6 \mathrm{a}$ & $6.9 \pm 1.6 \mathrm{a}$ & $7.6 \pm 0.7 \mathrm{a}$ \\
carbohydrates & & &
\end{tabular}

Notes: see in Table 1.

litter and the smallest in sessile oak (strongest mineralization of $\mathrm{P}$ ).

The mean dry mass of pedunculate oak leaf litter was $381 \pm 90$, hybrid oak $-508 \pm 141$ and sessile oak $-395 \pm 92 \mathrm{~g} \mathrm{~m}^{-2}$. The mean mass of hybrid oak leaf litter was about $21-25 \%$, but not significantly $(\mathrm{p}>0.05)$ higher than pedunculate and sessile oaks. However, the calculated mean stocks of N, C, lignin and CF were significantly (21-33\%) higher in the leaf litter of hybrids compared with pedunculate and sessile oaks (Table 2). Mean mass lignin/ $\mathrm{N}$ ratio

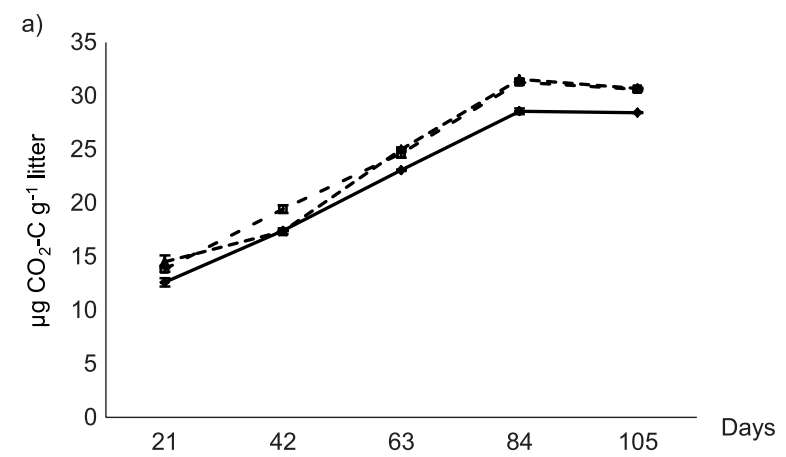

b)

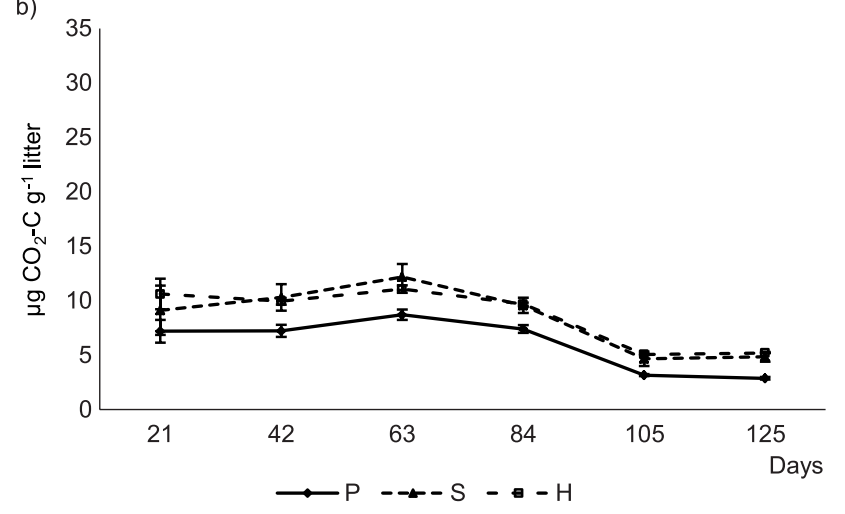

Fig. 2. Mean carbon release as $\mathrm{CO}_{2}\left(\mu \mathrm{g} \mathrm{CO}-\mathrm{CO}_{2} \mathrm{~g}^{-1} \pm \mathrm{SE}\right)$ during incubation period from the autumn leaf litterfall of pedunculate $(\mathrm{P})$ and sessile (S) oaks and their hybrids (H): a) in 2011 for 105 and b) in 2012 for 125 days period a)

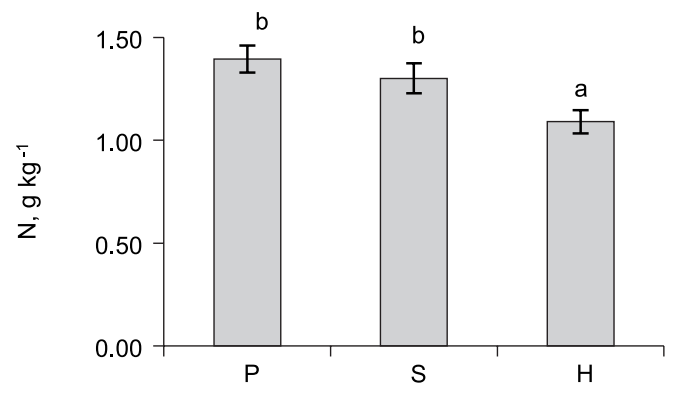

b)

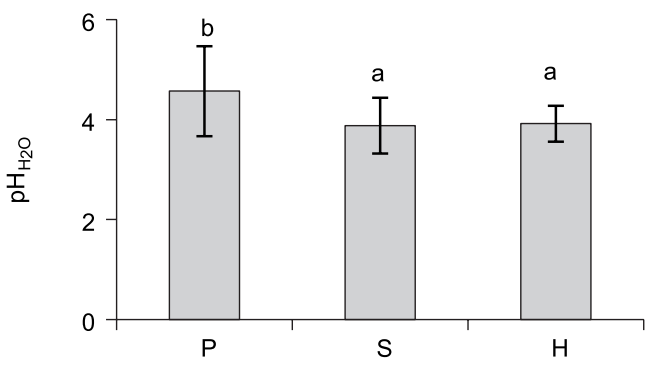

Fig. 3. Some chemical characteristics (mean for 2011-2012 $\pm \mathrm{SE} ; \mathrm{n}=9)$ of mineral top soil $(0-15 \mathrm{~cm})$ under pedunculate $(\mathrm{P})$ and sessile $(\mathrm{S})$ oaks and their hybrids $(\mathrm{H})$ : a) total nitrogen $(\mathrm{N})$; b) $\mathrm{pH}_{\mathrm{H} 2 \mathrm{O}}$ Means with different letters are significantly different $(\mathrm{p} \leq 0.05)$

significantly differed $(\mathrm{p}<0.05)$ only for pedunculate and hybrid oaks. Significant differences of stocks of other chemical characteristics of leaf litter of different oak species and their hybrids were not found.

Biochemical characteristics of leaf litter can affect the chemical composition of mineral top soil (Baldrian \& Štursova, 2011). In our study we found that mineral topsoil acidity under pedunculate oak was statistically less $(\mathrm{p}<0.05)(\mathrm{pH}$ value was on average higher by $0.1-0.2 \mathrm{pHH}_{2} \mathrm{O}$ ), and mean $\mathrm{N}$ concentrations in this soil were $8-27 \%$ higher than under pedunculate and sessile oaks (Fig. 3). However, low mean $\mathrm{C} / \mathrm{N}$ ratios (19-24) indicated a high rate of humification and slow mineralization of organic $\mathrm{N}$ in mineral topsoil under all studied oaks. A. HagenThorn et al. (2004) found that soil C, N and C/N ratios did not differ significantly among six European tree species.

\section{Foliar litter decomposition rate}

The decomposition rate of leaf litter evaluated according to $k_{W}$ was 0.0017 for to pedunculate oak, 0.0020 to sessile oak and 0.0019 to hybrid oak. Mean $k_{W}$ for sessile and hybrid oaks was at the same level while it was $11-15 \%$ lower for pedunculate oak (p $<0.05)$.

As can be seen from Fig. 2, the respiration of the leaf litter from the studied oaks in 2011 and 2012 was significantly different, due to the difference in precipitation amount in given years. The amount of 
precipitation in 2011 was two times lower than in 2012 (see chapter "Study site and sampling"). However, mean total carbon release calculated as $\mathrm{CO}_{2}$ from leaf litter of sessile and hybrid oaks did not differ $(\mathrm{p}>0.05)$ in both years. Meanwhile, compared with the above-mentioned oaks, mean total carbon release from the litter of pedunculate oak in 2011 was $7-10 \%$ lower after $63-105$ days of incubation. In 2012, these differences were more evident: mean total carbon release after 42-84 days was on average $29-42 \%$, and after $105-125$ days was $47-80 \%$ lower.

A more intense $k_{W}$ of the leaf litter of sessile oak compared with decomposition of leaf litter of pedunculate oak has been also obtained by laboratory tests

Dehydrogenase,

$\mu \mathrm{g}$ TPF $\mathrm{g}^{-1} \mathrm{DW} \mathrm{h}^{-1}$

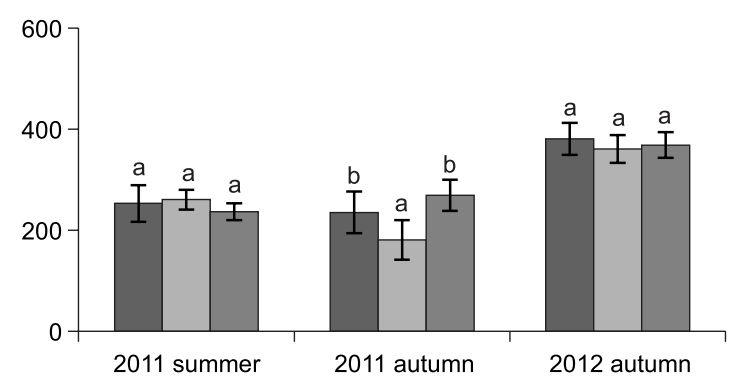

Phosphatase,

$\mu \mathrm{g} \mathrm{p}-\mathrm{NP} \mathrm{g}^{-1}$ DW $\mathrm{h}^{-1}$

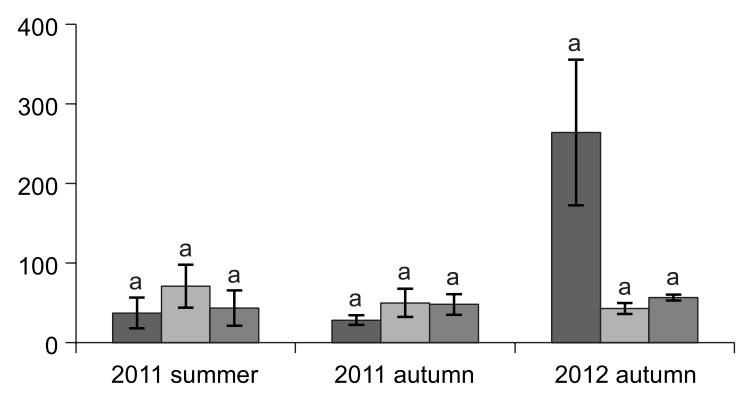

carried out by Straigytė et al. (2006). As in our studies, the significantly lower lignin concentration in sessile oak leaf litter reflected a higher $k_{W}$ and lower total release of $\mathrm{CO}_{2}$.

\section{Biological activity of mineral soil}

As can be seen in Fig. 4, soil enzyme activity of the studied oak species and their hybrids in general was similar ( $p>0.05$ ) during all periods of the study. For example, dehydrogenase in the autumn of 2011 was significantly less $(\mathrm{p}<0.05)$, only about $30-50 \%$, in the soil under sessile oak than under pedunculate and hybrid oaks. However, mean activity

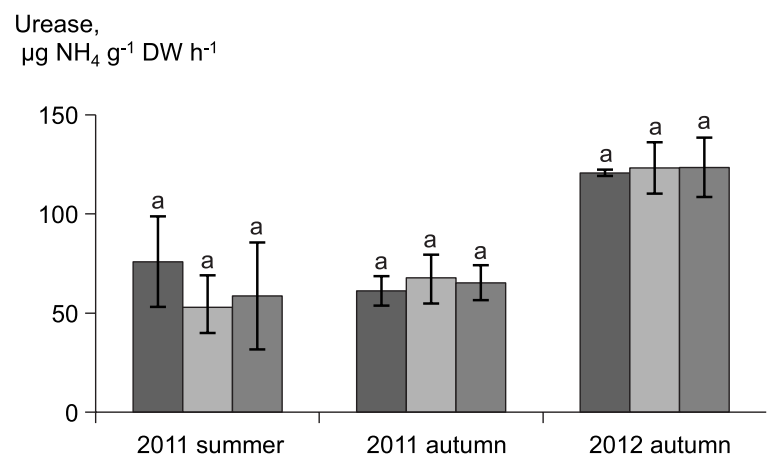

Bacteria,

106 x CFU g ${ }^{-1}$

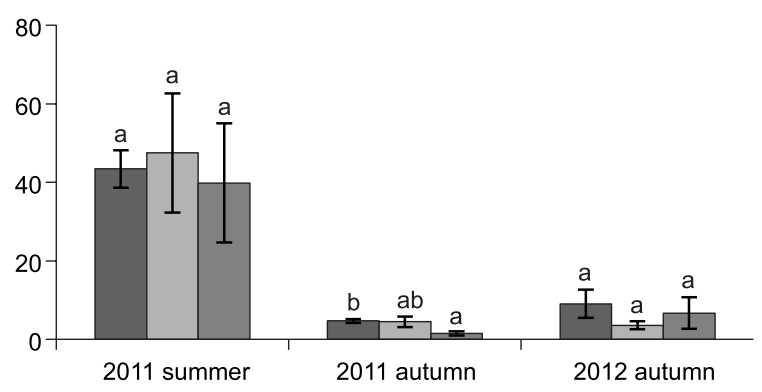

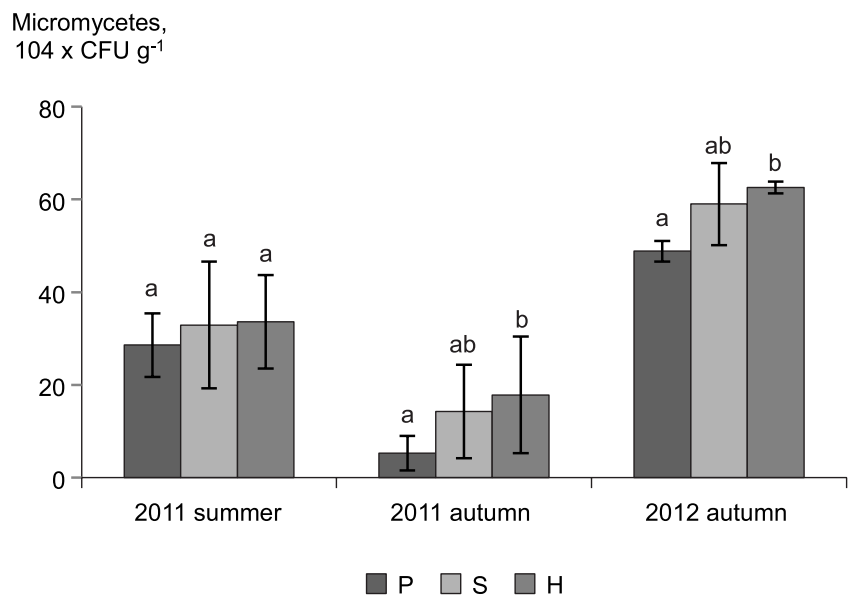

Fig. 4. Mean activity $( \pm \mathrm{SE}$ ) in mineral top soil (at $0-15 \mathrm{~cm})$ under pedunculate $(\mathrm{P})$ and sessile $(\mathrm{S})$ oaks and their hybrids $(\mathrm{H})$. Means with different letters are significantly different $(\mathrm{p}<0.05)$ for separate study periods (spatial analysise) 
of dehydrogenase and urease obtained in autumn 2012 was 1.2-2.3 times higher than in autumn 2011 $(\mathrm{p}<0.05)$. This could be explained by the fact that the environmental conditions in 2012 were more favourable (mainly twice higher amount of precipitation) for soil microbiological activity (Criquet et al., 2002; 2004; Sardans \& Peñuelas, 2005).

Mean activity of phosphatase enzymes did not significantly differ $(p>0.05)$ in the soil under all studied oaks (Fig. 4). The activity of phosphatase enzymes found in the soil under pedunculate oak in 2012 was, on average, 7-9 times higher $(p>0.05)$ compared with the soil under sessile and hybrid oaks, but even this was not essential because of the large variation in the data obtained.

The density of soil heterotrophic bacteria was significantly (9-26 times) higher $(\mathrm{p}<0.001)$ in the soil collected from the study area in summer compared to autumn soil samples (Fig. 4). That shows that heterotrophic bacteria are much more active in the summer (Morris, 1999; Sardans \& Peñuelas 2005; Šnajdr et al., 2008; Baldrian et al., 2013). In addition, the mean density of bacteria found in soil under pedunculate oaks in autumn 2011 was three times higher $(p<0.05)$ than in the soil under hybrid oaks.

In general, in all cases, the highest density of micromycetes was found in the soil under hybrid oak and the lowest in the soil of pedunculate oak (Fig. 4). No significant differences $(p>0.05)$ were found in the summer of 2011. In the autumn both of 2011 and 2012, the mean density of micromycetes in soil under hybrid oak was 1.3-2.6 times higher than under pedunculate oak. However, the abundance of soil

Table 3. Mean indices ( \pm SE) of metabolic activity of microorganisms in mineral soil (at $0-15 \mathrm{~cm}$ depth) under pedunculate $(\mathrm{P})$ and sessile $(\mathrm{B})$ oaks and their hybrids $(\mathrm{H})$ in Trakas Forest, Lithuania

\begin{tabular}{cccc}
\hline Species & 2011 & 2012 & Average \\
\hline \multicolumn{4}{c}{ Carbon substrate use, AWCD } \\
\hline $\mathrm{P}$ & $0.70 \pm 0.08$ & $0.65 \pm 0.21$ & $0.68 \pm 0.05$ \\
$\mathrm{~S}$ & $0.83 \pm 0.11$ & $0.74 \pm 0.09^{*}$ & $0.80 \pm 0.08$ \\
$\mathrm{H}$ & $0.78 \pm 0.07$ & $0.60 \pm 0.03^{*}$ & $0.71 \pm 0.05$ \\
\hline \multicolumn{5}{c}{ Shannon's diversity index, Sh } \\
\hline $\mathrm{P}$ & $2.98 \pm 0.23$ & $3.16 \pm 0.12$ & $3.05 \pm 0.14$ \\
$\mathrm{~S}$ & $3.10 \pm 0.20$ & $3.29 \pm 0.06$ & $3.18 \pm 0.12$ \\
$\mathrm{H}$ & $3.11 \pm 0.10$ & $3.19 \pm 0.05$ & $3.14 \pm 0.06$ \\
\hline \multicolumn{5}{c}{ Evenness of substrate, E } \\
\hline $\mathrm{P}$ & $0.98 \pm 0.01$ & $0.97 \pm 0.012$ & $0.97 \pm 0.006$ \\
$\mathrm{~S}$ & $0.98 \pm 0.003$ & $0.99 \pm 0.006$ & $0.98 \pm 0.003$ \\
$\mathrm{H}$ & $0.97 \pm 0.01$ & $0.98 \pm 0.002$ & $0.97 \pm 0.006$ \\
\hline \multicolumn{5}{c}{ Richness of substrate, $\mathrm{R}$} \\
$\mathrm{P}$ & $22.50 \pm 3.97$ & $25.67 \pm 2.02$ & $23.86 \pm 2.34$ \\
$\mathrm{~S}$ & $25.25 \pm 4.09$ & $28.00 \pm 1.15$ & $26.43 \pm 2.29$ \\
$\mathrm{H}$ & $24.25 \pm 1.80$ & $26.00 \pm 1.00$ & $25.00 \pm 1.09$ \\
\hline
\end{tabular}

*Significant differences between sessile and hybrid oaks, p < 0.001 . micromycetes under sessile oak was intermediate and did not differ $(\mathrm{p}>0.05)$ from the soil under pedunculate and hybrid oaks as well. This shows that, compared with other oaks, the abundance of fungi that decompose stable organic compounds was lower in mineral soil under pedunculate oak (Rodriguez et al., 1996; Setälä \& McLean, 2004).

The structure of microbial communities and their functions were compared with microbial carbon biomass and Biolog samples in the soil under the studied oak species. The study of the metabolic activity of soil microorganisms in general showed that the indices of metabolic diversity of microorganisms did not differ in the mineral soil under the studied oak species ( $p>0.05)$ (Table 3$)$. Only slightly higher ( $\mathrm{p}>0.05)$ Shannon's diversity index $(S h)$, evenness of substrate (E) and richness of substrate $(R)$ were determined in the soil under sessile oak. Meanwhile, the potential for carbon substrate use, defined by AWCD, was on average $20 \%$ higher in the soil under sessile oak and lowest $(\mathrm{p}<0.05)$ in the soil of hybrid oak in autumn 2012. AWCD reflects the capability of soil microbiota communities to use carbon sources, so it could be an important microbiota activity indicator (Zabinski \& Gannon, 1997).

Reviewing some obtained data, the lower $\mathrm{CO}_{2}$ emission from forest leaf litter decomposition in 2012 with greater precipitation could be explained by fact that higher than normal rainfall inhabits soil $\mathrm{CO}_{2}$ exchange range (Raich et al., 2002). On the other hand, in dry forest sites the increase of soil moisture normally increases the soil bioactivity, e.g. the activities of dehydrogenase and urease. The abundance of micromycetes could increase the increase of soil moisture, as well. However, the micromycetes mainly decompose stabile complex organic matter, therefore, in initial stage they did not affect $\mathrm{CO}_{2}$ emission rate of the soil significantly (Treseder \& Lennon, 2015).

Pedunculate and sessile oaks are taxonomically related, belong to the same genus and grow together in a restricted geographical area and this is not surprising that there were no significant differences between both species and their hybrids. However, summarizing these results, it might be noted, that the sessile oak leave litter are distinguished by lower hard-biodegradable lignin concentrations. This has led to a faster decomposition of sessile oak leave litter. Metabolic activity and diversity of microorganisms also was slightly higher in the soil under sessile oak. Hybrid oak rates little differed from the sessile oak. Therefore, we can assume that due to the higher decomposition rate of forest floor in Trakas Forest (Alytus district in Lithuania) favourable conditions for sessile and hybrid oak undergrowth spread was formed. 


\section{Conclusion}

Autumn leaf litterfall mass and biochemical composition of pedunculate (Quercus robur) and sessile (Q. petraea) oaks and their hybrids differed in general insignificantly and the significant differences in mean concentrations and stocks of $\mathrm{N}, \mathrm{C}$, lignin and crude fibre did not exceed $20-30 \%(p<0.05)$. However, the highest content of lignin and higher lignin/ $\mathrm{N}$ ratio, lower decay rate and, especially, lower carbon release indicated $(\mathrm{p}<0.05)$ the slowest decomposition of pedunculate oak litterfall compared with sessile and hybrid oaks.

The rhizosphere under the studied oaks did not differ significantly in terms of $\mathrm{C}$ concentration and $\mathrm{C} / \mathrm{N}$ ratio, mean activities of dehydrogenase, urease, and phosphatase, abundance of bacteria, and metabolic activity of soil microorganisms. However, the lowest activity of micromycetes showed that, under pedunculate oak, the decomposition of stable organic compounds was less intensive than in the rhizosphere of sessile and hybrid oaks.

Metabolic activity (indicated as Shannon's diversity index, evenness and richness of substrate) of microorganisms differed insignificantly in the rhizosphere of the studied oaks. However, the potential for the use of different carbon compound substrates microorganisms had a tendency to be higher in the soil under sessile oak.

The decomposition rate of leaves litterfall and organic compounds in the rhizosphere under sessile and hybrid oaks were more intensive compared to pedunculate oak. Therefore, it could be supposed the conditions, mainly higher decomposition rate of litterfall for natural regeneration of undergrowth were more suitable in the stands where sessile and hybrid oaks dominate.

\section{Acknowledgment}

The paper presents research findings which have been obtained through the long-term research programme 'Sustainable Forestry and Global Changes' implemented by the Lithuanian Research Centre for Agriculture and Forestry.

\section{References}

Aas G (1993) Taxonomical impact of morphological variation in Quercus robur and Q. petraea: a contribution to the hybrid controversy. Annales des Sciences Forestières 50: 107-113.

Amador JA, Glucksman AM, Lyons JB \& Görres JH (1997) Spatial distribution of soil phosphatase activity within a riparian forest. Soil Science 162: 808-825.
Aon MA, Cabello MN, Sarena DE, Colaneri AC, Franco MG, Burgos JL \& Cortassa S (2001) I. Spatio-temporal patterns of soil microbial and enzymatic activities in an agricultural soil. Applied Soil Ecology 18: 239-254.

Ayres E, Dromph KM \& Bardgett RD (2006) Do plant species encourage soil biota that specialise in the rapid decomposition of their litter? Soil Biology and Biochemistry 38: 183-186.

Baldrian P, Šnajdr J, Merhautová V, Dobiášová P, Cajthaml T \& Valášková V (2013) Responses of the extracellular enzyme activities in hardwood forest to soil temperature and seasonality and the potential effects of climate change. Soil Biology and Biochemistry 56: 60-68.

Baldrian P \& Štursová M (2011) Enzymes in forest soils: Soil enzymology (ed. by G Shukla \& A Varma) Soil biology 22, Springer, Berlin, Heidelberg, pp. 61-73. doi:10.1007/978-3-642-14225-3 4.

Baliuckas V (2000) Paprastojo (Quercus robur) ir bekočio ąžuolo ( $Q$. petraea) rūšiu introgresija Trako miške (Introgression of pedunculate (Quercus robur) and sessile (Q. petraea) oak species in Trakas forest. Botanica Lithuanica 6: 375-387.

Bolton H, Elliott LF, Papendick RI \& Bezdicek DF (1985) Soil microbial biomass and selected soil enzyme activities: effect of fertilization and cropping practices. Soil Biology and Biochemistry 17: 297-302.

Carlisle A \& Brown AMF (1965) The assessment of the taxonomic status of mixed oaks (Quercus ssp.) populations. Watsonia 6: 120-127.

Chávez-Vergara B, Rosales-Castillo A, Merino A, Vázquez-Marrufo G, Oyama K \& García-Oliva F (2016) Quercus species control nutrients dynamics by determining the composition and activity of the forest floor fungal community. Soil Biology and Biochemistry 98: 186-195.

Criquet S, Ferre E, Farnet AM \& Le Petit J (2004) Annual dynamics of phosphatase activities in an evergreen oak litter: influence of biotic and abiotic factors. Soil Biology and Biochemistry 36: $1111-1118$.

Criquet S, Tagger S, Vogt G \& Le Petit J (2002) Endoglucanase and b-glycosidase activities in an evergreen oak litter: annual variation and regulating factors. Soil Biology and Biochemistry 34: $1111-1120$.

Das SK \& Varma A (2011) Role of enzymes in maintaining soil health: Soil enzymology (ed. by G Shukla \& A Varma) Soil biology 22, Springer, Berlin, Heidelberg, pp. 25-42. doi:10.1007/9783-642-14225-3 2.

DIN-ISO 13878 (1998) Bodenbeschaffenheit - Bestimmung des Gesamt-Stickstoffs durch trockene Verbrennung (Elementaranalyse). Beuth, Berlin, Wien, Zürich. 
Edmonds RL (1979) Decomposition and nutrient release in Douglas-fir needle litter in relation to stand development. Canadian Journal of Forest Research 9: 132-140.

Edmonds RL (1980) Litter decomposition and nutrient release in Douglas-fir, red alder, western hemlock, and Pacific silver fir ecosystems in western Washington. Canadian Journal of Forest Research 10: 327-337.

Galvonaitė A, Kilpys J, Kitrienè Z \& Valiukas D (2013) Vudutinių klimatinių rodiklių reikšmès Lietuvoje 1981-2010 m./Climate average for Lithuania 1981-2010. http://www.meteo.lt/dokumentai/literatura/Brosiura/Lietuvos_klimatas_09_25.pdf.

Gosz JR, Likens GE \& Bormann FH (1973) Nutrient release from decomposing leaf and branch litter in the Hubbard Brook Forest, New Hampshire. Ecological monographs 43: 173-191.

Guan SY (1989) Studies on the factors influencing soil enzyme activities: I. Effects of organic manures on soil enzyme activities and $\mathrm{N}$ and $\mathrm{P}$ transformations. Acta Pedologica Sinica 26: 72-78.

Hagen-Thorn A, Callesen I, Armolaitis K \& Nihlgård B (2004) The impact of six European tree species on the chemistry of mineral topsoil in forest plantations on former agricultural land. Forest Ecology and Management 195: 373-384.

Hart SC, Firestone MK \& Paul EA (1992) Decomposition and nutrient dynamics of Ponderosa pine needles in a Mediterranean-type climate. Canadian Journal of Forest Research 22: 306-314.

Hobbie SE, Reich PB, Oleksyn J, Ogdahl M, Zytkowiak R, Hale C \& Karolewski P (2006) Litter decomposition in a common garden experiment with fourteen tree species. Ecology 87: 2288-2297.

Hussain S, Siddique T, Saleem M, Arshad M \& Khalid A (2009) Impact of pesticides on soil microbial diversity, enzymes, and biochemical reactions. Advances in Agronomy 102: 159-200.

Insam H \& Goberna M (2004) Use of Biolog ${ }^{\circledR}$ for the community level physiological profiling (CLPP) of environmental samples: Molecular microbial ecology manual. Second edition, pp. 853-860.

ISO 11465: 1993. Soil quality - determination of dry matter and water content on a mass basis - gravimetric method.

Janušauskaitė D, Baliuckas V \& Dabkevičius Z (2013) Needle litter decomposition of native Pinus sylvestris L. and alien Pinus mugo at different ages affecting enzyme activities and soil properties on dune sands. Baltic Forest 19: 50-60.

Jensen J, Larsen A, Nielsen LR \& Cottrell J (2009) Hybridization between Quercus robur and Q. petraea in a mixed oak stand in Denmark. Annals of Forest Science 66: 706. doi:10.1051/forest/2009058.
Jordan D \& Kremer RJ (1994) Potential use of soil microbial activity as an indicator of soil quality. Soil biota: management in sustainable farming systems, CSIRO Australia, pp. 245-249.

Jurkšienė G \& Baliuckas V (2014) Leaf morphological variation of sessile oak (Quercus petraea (Matt.) Liebl.) and pedunculate oak (Quercus robur L.) in Lithuania. Proceedings of the Annual 20th International Scientific Conference: research for rural development 2014. Jelgava 2: 63-69.

Jurkšienè G, Janulionis G \& Baliuckas V (2012) Paprastojo, bekočio ąžuolų ir jų hibridų paplitimas Trako miške bei ši procesą sąlygojantys veiksniai. Miškininkystė 1: 40-48.

Kaiser C, Fuchslueger L, Koranda M, Gorfer M, Stange CF, Kitzler B, Rasche R, Strauss J, Sessitsch A, Zechmeister-Boltenstern S \& Richter A (2011) Plants control the seasonal dynamics of microbial $\mathrm{N}$ cycling in a beech forest soil by belowground $\mathrm{C}$ allocation. Ecology 92: 1036-1051.

Kandeler E (1996) Urease activity by colorimetric technique: Methods in soil biology (ed. by $\mathrm{F}$ Schinner, R Öhlinger, E Kandeler \& R Margesin) Springer, Berlin, pp. 171-174.

Karaca A, Cetin SC, Turgay OC \& Kizilkaya R (2011) Soil enzymes as indication of soil quality: Soil enzymology (ed. by G Shukla \& A Varma) Soil biology 22, Springer, Berlin, Heidelberg, pp. 119-148. doi:10.1007/978-3-642-14225-3_7.

Kissling P (1980a) Un réseau de corrélations entre les chênes (Quercus) du Jura. Berichte-Schweizerische Botanische Gesellschaft 90: 1-28.

Kissling P (1980b) Clef de détermination des chênes médioeuropéens (Quercus L.). Berichte-Schweizerische Botanische Gesellschaft 90: 29-44.

Kissling P (1983) Les chênaies du Jura central suisse. Thesis, Université de Lausanne, Switzerland.

Koerselman W \& Meuleman AFM (1996) The vegetation $\mathrm{N}: \mathrm{P}$ ratio: a new tool to detect the nature of nutrient limitation. Journal of Applied Ecology 33: 1441-1450.

Krämer S \& Green DM (2000) Acid and alkaline phosphatase dynamics and their relationship to soil microclimate in semiarid woodland. Soil Biology and Biochemistry 32: 179-188.

LHMT/AM (2011a) Meteorologinis biuletenis. Lietuvos Hidrometeorologijos Tarnyba, Vilnius 6: 900.

LHMT/AM (2011b) Meteorologinis biuletenis. Lietuvos Hidrometeorologijos Tarnyba, Vilnius 11: 905.

LHMT/AM (2012) Meteorologinis biuletenis. Lietuvos Hidrometeorologijos Tarnyba Vilnius 11: 917.

LR AM/LMI/MVT (2006) Miško augaviečiu tipai (ed. by M Vaičys) Kaunas, Lututė.

Margesin R (1996) Acid and alkaline phosphomonoesterase activity with the substrate p-nitrophe- 
nyl phosphate: Methods in soil biology (ed. by F Schinner, R Öhlinger, E Kandeler \& R Margesin) Springer, Berlin, pp. 213-217.

Minihan VB \& Rushton BS (1984) The taxonomic status of oaks (Quercus ssp.) in Breen Wood, Co Antrim, Northern Ireland. Watsonia 15: 27-32.

Moore TR, Trofymow JA, Prescott CE, Fyles J \& Titus BD (2006) Patterns of carbon, nitrogen and phosphorus dynamics in decomposing foliar litter in Canadian forests. Ecosystems 9: 46-62.

Morris SM Jr (1999) Arginine synthesis, metabolism, and transport: regulators of nitric oxide synthesis: Cellular and molecular biology of nitric oxide (ed. by JD Laskin \& DL Laskin) Marcel Dekker, Inc., New York, pp. 57-85.

Navasaitis M, Ozolinčius R, Smaliukas D \& Balevičienè J (2003) Lietuvos dendroflora. Lututè, Kaunas.

Öhlinger R (1996) Soil sampling and sample preparation: Methods in soil biology (ed. by F Schinner, R Öhlinger, E Kandeler \& R Margesin) Springer, Berlin, pp. 7-11.

Olson JS (1963) Energy storage and the balance of producers and decomposers in ecological systems. Ecology 44: 322-331.

Osman KT (2013) Forest soils: Soils (ed. by KT Osman) Springer, Netherlands, pp. 229-251.

Osono T \& Takeda H (2004) Accumulation and release of nitrogen and phosphorus in relation to lignin decomposition in leaf litter of 14 tree species. Ecological Research 19: 593-602.

Patalauskaite D (2007) Communities of Quercus petraea in Lithuania. Acta Biologica Universitatis Daugavpiliensis 7: 159-164.

Patalauskaite D (2008) On the quercetalia robori-petraeae in Lithuania. Botanica Lithuanica 14: 113-119.

Piatek KB, Munasinghe P, Peterjohn WT, Adams MB \& Cumming JR (2009) Oak contribution to litter nutrient dynamics in an Appalachian forest receiving elevated nitrogen and dolomite. Canadian Journal of Forest Research 39: 936-944.

Quilchano C \& Maranon T (2002) Dehydrogenase, activity in Mediterranean forest soils. Biology and Fertility of Soils 35: 102-107.

Raich JW, Potter CS \& Bhagawati D (2002) Interannual variability in global soil respiration, 198094. Global Change Biology 8: 800-812.

Rodriguez A, Perestelo F, Carnicero A, Regalado V, Perez R \& Falcon MA (1996) Degradation of natural lignins and lignocellulosic substrates by soil-inhabiting fungi imperfecti. FEMS Microbiology Ecology 21: 213-219.

Rushton BS (1978) Quercus robur L. and Quercus petraea (Matt.) Liebl.: a multivariate approach to the hybrid problem. 1. Data acquisition, analysis and interpretation. Watsonia 12: 81-101.
Rushton BS (1979) Quercus robur L. and Quercus petraea (Matt.) Liebl.: a multivariate approach to the hybrid problem. 2. The geographical distribution of population types. Watsonia 12: 209-224.

Rushton BS (1983) An analysis of variation of leaf characters in Quercus robur L. and Quercus petraea (Matt.) Liebl. population samples from Northern Ireland. Irish Forestry 40: 52-77.

Rustad LE \& Cronan CS (1988) Element loss and retention during litter decay in a red spruce stand in Maine. Canadian Journal of Forest Research 18: 947-953.

Sardans J \& Peñuelas J (2005) Drought decreases soil enzyme activity in a Mediterranean Quercus ilex L. forest. Soil Biology and Biochemistry 37: 455-461.

Setälä H \& McLean MA (2004) Decomposition rate of organic substrates in relation to the species diversity of soil saprophytic fungi. Oecologia 139: 98-107.

Sinsabaugh RL, Carreiro MM \& Repert DA (2002) Allocation of extracellular enzymatic activity in relation to litter composition, $\mathrm{N}$ deposition, and mass loss. Biogeochemistry 60: 1-24.

Šnajdr J, Valášková V, Merhautová V, Herinková J, Cajthaml T \& Baldrian P (2008) Spatial variability of enzyme activities and microbial biomass in the upper layers of Quercus petraea forest soil. Soil Biology and Biochemistry 40: 2068-2075.

Steinhoff S (1998) Kontrollierte kreuzungen zwischen stiel- und traubeneiche: ergebnisse und folgerungen. Allgemeine Forstund. Jagdzeitung 169:163-168.

Straigytė L, Janušauskaitė D \& Bartkevičius E (2006) Ązžuolų lapų irimo intensyvumas ir įtaka dirvožemiui. Vagos: Mokslo Darbai 73: 13-18.

Streiff R, Ducousso A, Lexer C, Steinkellner H, Gloessl J \& Kremer A (1999) Pollen dispersal inferred from paternity analysis in a mixed oak stand of Quercus robur L. and Q. petraea (Matt.) Liebl. Molecular Ecology 8: 831-841.

Strickland MS, McCulley RL \& Bradford MA (2013) The effect of a quorum-quenching enzyme on leaf litter decomposition. Soil Biology and Biochemistry 64: 65-67.

Tabatabai MA \& Bremner JM (1972) Assay of urease activity in soils. Soil Biology and Biochemistry 4: 479-487.

Treseder KK \& Lennon JT (2015) Fungal traits that drive ecosystem dynamics on land. Microbiology and Molecular Biology Reviews 79: 243-262.

Trolldenier G (1996) Plate count technique: Methods in soil biology (ed. by F Schinner, R Öhlinger, E Kandeler, R Margesin) Springer, Berlin, pp. 20-26.

Tuminauskas S (1957) Bekotis ąžuolas pietų Lietuvoje (Sessile oak in southern Lithuania). Mūsų Girios 5: 11-13. 
Utobo EB \& Tewari L (2015) Soil enzymes as bioindicators of soil ecosystem status. Applied Ecology and Environmental Research 13: 147-169. doi: 10.15666/aeer/1301_147169.

Van Soest PJ, Robertson JB \& Lewis BA (1991) Methods for dietary fiber, neutral detergent fiber, and nonstarch polysaccharides in relation to animal nutrition. Journal of Dairy Science 74: 3583-3597.

Wigston DL (1975) The distribution of $Q$. robur L., Q. petraea (Matt.) Leibl. and their hybrids in south-western England. 1. The assessment of the taxonomic status of populations from leaf characters. Watsonia 10: 345-369.
WRB (2014) World Reference Base for Soil Resources 2014. International soil classification system for naming soils and creating legends for soil maps. World Soil Resources Reports No. 106. FAO, Rome.

Yang ZX, Liu SQ, Zheng DW \& Feng SD (2006) Effects of cadium, zinc and lead on soil enzyme activities. Journal of Environmental Sciences 18: 1135-1141.

Zabinski CA \& Gannon JE (1997) Effects of recreational impacts on soil microbial communities. Environmental Management 21: 233-238. 